\title{
Article \\ Study of Cyberbullying among Adolescents in Recent Years: A Bibliometric Analysis
}

\author{
Ana Belén Barragán Martín ${ }^{1}{ }^{1}$, María del Mar Molero Jurado ${ }^{1, *} \mathbb{C}$, María del Carmen Pérez-Fuentes ${ }^{1} \mathbb{1}$, \\ María del Mar Simón Márquez ${ }^{1}$, África Martos Martínez ${ }^{1}{ }^{1}$, Maria Sisto ${ }^{1}$ and José Jesús Gázquez Linares ${ }^{1,2}$ \\ 1 Department of Psychology, Faculty of Psychology, University of Almería, 04120 Almería, Spain; \\ abm410@ual.es (A.B.B.M.); mpf421@ual.es (M.d.C.P.-F.); msm112@ual.es (M.d.M.S.M.); \\ amm521@ual.es (Á.M.M.); ms168@ual.es (M.S.); jlinares@ual.es (J.J.G.L.) \\ 2 Department of Psychology, Universidad Autónoma de Chile, Providencia 7500000, Chile \\ * Correspondence: mmj130@ual.es; Tel.: +34-950-015-598
}

Citation: Barragán Martín, A.B.;

Molero Jurado, M.d.M.;

Pérez-Fuentes, M.d.C.; Simón

Márquez, M.d.M.; Martos Martínez,

Á.; Sisto, M.; Gázquez Linares, J.J.

Study of Cyberbullying among

Adolescents in Recent Years: A

Bibliometric Analysis. Int. J. Environ.

Res. Public Health 2021, 18, 3016.

https://doi.org/10.3390/ijerph18063016

Academic Editors:

Rosario Ortega-Ruiz, Lourdes Rey,

María Angeles Peláez-Fernández and Cirenia Quintana-Orts

Received: 26 January 2021

Accepted: 11 March 2021

Published: 15 March 2021

Publisher's Note: MDPI stays neutral with regard to jurisdictional claims in published maps and institutional affiliations.

Copyright: (c) 2021 by the authors. Licensee MDPI, Basel, Switzerland. This article is an open access article distributed under the terms and conditions of the Creative Commons Attribution (CC BY) license (https:// creativecommons.org/licenses/by/ $4.0 /)$.

\begin{abstract}
In recent years, cyberbullying has been recognized as a severe public health problem and is drawing growing interest. The objective of this study was to perform a bibliometric analysis of the scientific production on adolescent cyberbullying in the last decade. A search for publications was made in the Web of Science database, where the 1530 documents identified were analyzed with BibExcel software and visualized using the Pajek and VOSviewer tools. The predominant language in the publications was English, followed by Spanish. The publication rate was shown to have increased in recent years. The journal "Computers in Human Behavior" had the highest production. The repercussion of new technologies on this phenomenon has been felt, and research groups have enlarged their production in response to the problem. A systematic review and/or meta-analysis examining the contents of the studies identified and the variables related to this problem is therefore necessary. This could identify a point of reference for research in this field and a basis for future reviews of its development and progress over time.
\end{abstract}

Keywords: cyberbullying; adolescents; bibliometric analysis; co-authorship network; publications

\section{Introduction}

Social relations during adolescence are essential to individual psychological wellbeing [1] and social development [2], because it is when one begins to learn to interact with society, to create the first friendships, and to resolve the first conflicts, which can sometimes turn violent [3,4], as in bullying [5,6]. Such situations usually have negative repercussions on the lives of young people who have been involved in them. However, bullying takes place not only in the school. With the development of new information and communication technologies, cyberbullying has emerged [7]. The strong impact of the constant increment and dependence on ICTs has changed the content, habits, and forms of interpersonal relations [8]. Both bullying and cyberbullying have been recognized as a severe public health problem $[9,10]$, as they represent a threat to the development of the mental health and well-being of children and adolescents [11]. Both refer to a type of violence, in which cyberbullying specifically uses ICTs to harass peers $[12,13]$. Cyberbullying victims are usually more emotionally and more severely affected than victims of traditional bullying. In most cases, the two phenomena coincide, but cyberbullying is not often discussed separately [14]. More so, there is co-occurrence between bullying and cyberbullying, in which some adolescents are cyberaggression victims [15].

Some studies suggest a prevalence of cyberbullying of $6.5 \%$ to $35.4 \%$ in Europe and the United States [16], although the prevalence of cyberbullying among adolescents varies depending on the factors evaluated $[17,18]$. Its appearance is linked to such traits as low self-esteem [19]; low affective and cognitive empathy [20]; social and psychologi- 
cal maladjustments [21,22]; states of depression, anxiety, and anger [23]; low academic performance [24]; school absenteeism [25]; and others.

There is no exact delimitation of the main risk and protection factors that predict cyberbullying; however, some individual, family, and social variables can be found [26]. Lower empathy and male sex [27] are mentioned as predictor variables, and physical aptitude as a possible protective factor [28]. In the family, indulgent and authoritarian parenting styles influence aggressive adolescent behavior, while styles showing the best results involve the warmth and affect of parents toward their children [29]. Even though there is a close relationship with social influences during adolescence, parenting styles are more predominant in the development of aggressiveness [30]. However, social influence can also have repercussions on the intention and behavior of cyberbullying [31], along with the use of social networks and texting, which are predictors of occasional cyberbullying [26,32].

The scientific production on this phenomenon has been reviewed and analyzed in systematic reviews of databases $[16,33]$ by bibliometric analysis. Bibliometric analysis can identify elements in the literature, such as the most productive authors, countries, institutions, and journals within an area of study, as well as trends in production and collaboration networks [34], and bibliometric mapping provides a description of publications on a structural level by visualizing production [35]. Herrera-López, Romera, and Ortega-Ruiz [36] performed a bibliometric study in Latin America, identifying bibliographic production on bullying and cyberbullying, and emphasized more research on the first phenomenon than on the second. Other studies that have reviewed cyberbullying in Spanish journals [37] have shown social networks to be the mobile communication tools with the most immediacy among youths, and have underlined the important role of intervention to prevent and reduce this type of violence $[38,39]$. English, the main language of communication and publication in research [40], is the predominant language of these studies.

In view of the above, the objective of this study was to analyze the evolution of this topic by employing the bibliometric method to acquire an overview of cyberbullying in the last 10 years through indicators, such as the number of publications, types of documents, countries and institutions, authors, and so forth. We also wanted to identity the trends in publications on cyberbullying in adolescents during this period.

\section{Materials and Methods}

Bibliometric analyses have become an additional tool for determining the quality of scientific literature and its repercussion on the population [41].

\subsection{Selecting the Database}

First, Web of Science, Scopus, and Psychology Database were compared for their use and relevance in the field, employing the terms "cyberbullying," "adolescent," "teenagers," and "adolescence." The search formula was (cyberbullying AND (adolescent OR youth OR teenagers OR adolescence)). The search for publications was limited to the period from 2010 to 2020.

After this preliminary analysis in each of the databases, we found that there were a similar number of documents in Scopus (1046) and Psychology Database (1017). However, there was a significant difference in scientific production related to the subject in Web of Science, where results were much higher.

\subsection{Data Collection and Search Strategy}

The Web of Science (WOS) database was therefore used in this study, limiting the search to publications from 1 January 2010 to 1 January 2020. The search equation was TS $=$ (cyberbullying AND (adolescent OR youth OR teenagers OR adolescence)), applying filters, such as type of document, and selecting articles in journals, whether open access or not. When all the filters had been selected, the results were imported from the database as unformatted text for later analysis. A total of 1530 documents were found. 


\subsection{Inclusion and Exclusion Criteria}

The inclusion criteria were (a) study on cyberbullying; (b) study population of adolescents, young people, or youth; (c) publication from 1 January 2010 to 1 January 2020; and (d) language being English or Spanish.

The exclusion criteria were studies that (a) were not on adolescence or about young university students and (b) did not use English or Spanish as publication language.

After applying the filters and inclusion and exclusion criteria, the 1530 documents the search had produced were reduced to 1276 .

\subsection{Data Analysis}

The files were downloaded from the Web of Science database separately as plain text, then combined and transformed so they could be read by BibExcel [42]. This program can manipulate and preprocess a large volume of data at the same time. Microsoft Excel (Microsoft Corporation, Redmond, WA, USA programs) was also used to count the data on language, journals, and countries and to calculate the trend of publications in cyberbullying in adolescents. All the analyses were performed on the 1276 documents, except for the language analysis, which was done on all 1530 articles. Pajek (developed by Andrej Mrvar and Vladimir Batagelj, University of Ljubljana, Slovenia) was used for the construction and visualization of the networks [43], and VOSviewer [44] (The Centre for Science and Technology Studies, Leiden, Netherlands) constructed the co-authorship and word networks.

\section{Results}

A total of 1530 files related to cyberbullying in adolescents found in the Web of Science database were analyzed with the following indicators to find out the type of studies done and the trend in the subject:

The predominant language of the publications, with $92.71 \%(n=1183)$, was English, followed by Spanish with $8 \%(n=102)$, French with $0.55(n=7)$, Portuguese with $0.31 \%$ $(n=4)$, and others with $0.31 \%(n=4)$.

Figure 1 presents the international scientific production of articles on adolescent cyberbullying, showing an increase in publications in the last 10 years. The first 4 years from 2010 through 2013 were less productive than the rest of the years, although there was an increase of 50 articles in 2011/2012. Starting in 2014, production began to increase, and the most productive period was 2017-2018, in which 51 more studies were published than the year before. In the following years, the trend in scientific production continued to rise $\left(R^{2}=0.971\right)$.

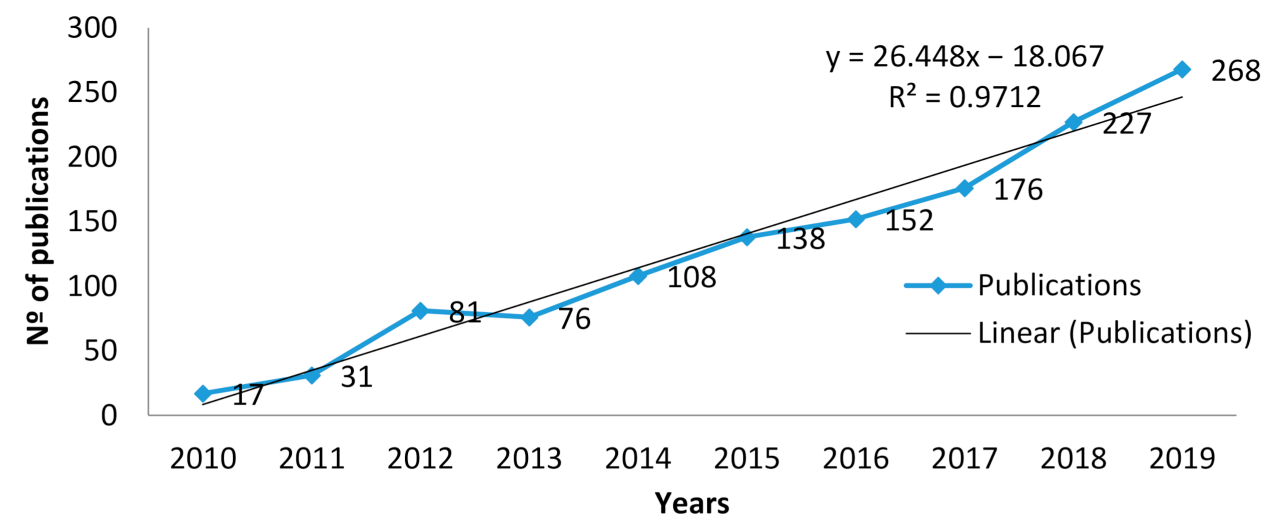

Figure 1. Scientific production on adolescent cyberbullying and its trend from 2010 to 2020.

Figure 2 shows the distribution of documents by country for the period from 2010 through 2019. The country with the most publications was the United States (355), followed 
by Spain (214), England (100), Australia (75), Canada (72), China (61), and Italy (60). Spain was the country with the second highest production on adolescent cyberbullying.

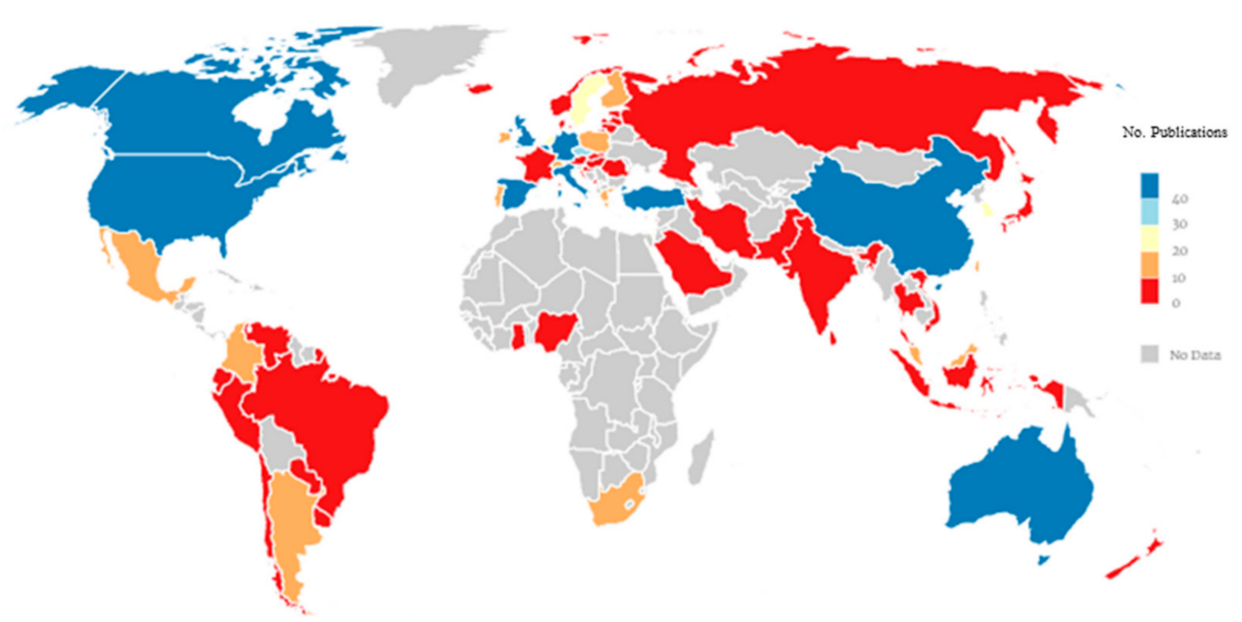

Figure 2. Trends in publications on adolescent cyberbullying by country.

Figure 3 shows the trend in publications on adolescent cyberbullying in each of the seven countries with the highest percentages of scientific production. The United States and Spain were the countries with the greatest increases.

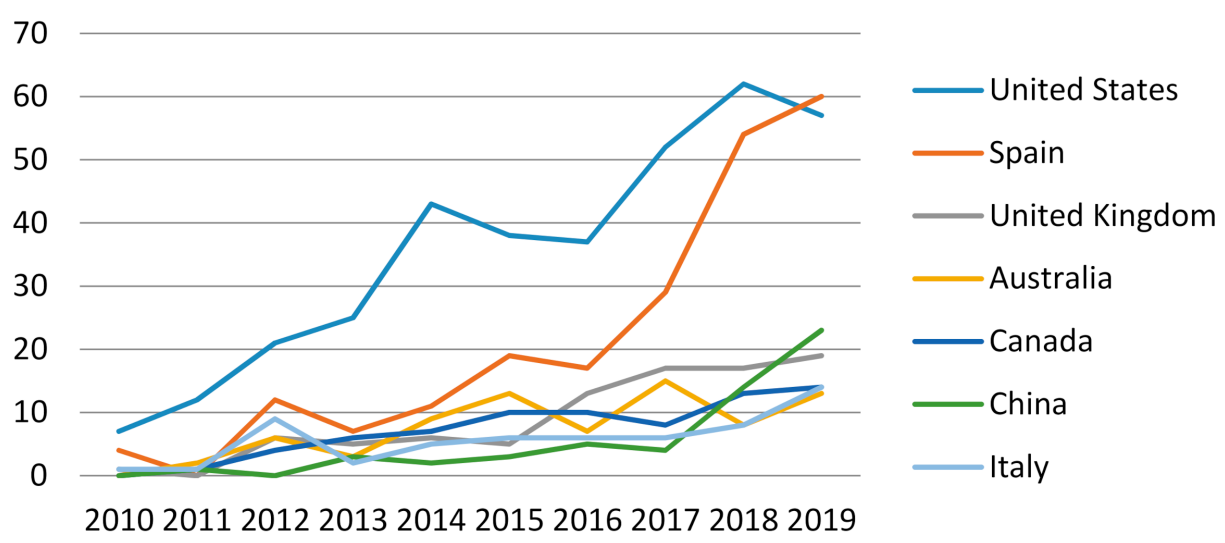

Figure 3. Trend in publications in countries with the highest production rates.

The general category with the most publications was social sciences, followed by scientific technology, life science and biomedicine, technology, and areas such as physical sciences, art, and humanities.

A total of 501 journals published articles on adolescent cyberbullying. Table 1 shows the 18 journals with the most articles. Computers in Human Behavior (101) published the most, followed by Cyberpsychology, Behavior, and Social Networking (43) and the International Journal of Environmental Research and Public Health (42). These journals rank in the first and second quartile in the SJR (SCImago Journal \& Country Rank), which is an indicator evaluating the importance and quality of a journal within its area. Most of the documents were published in journals in the United States, the United Kingdom, Spain and the Netherlands. 
Table 1. Selection of journals with the most publications on adolescent cyberbullying.

\begin{tabular}{lccccc}
\hline \multicolumn{1}{c}{ Journal } & $\begin{array}{c}\text { No. of } \\
\text { Publications }\end{array}$ & Quartile & SJR (2018) & H Index & Country \\
\hline Computers in Human Behavior & 101 & $\mathrm{Q} 1$ & 1.71 & 137 & United Kingdom \\
Cyberpsychology, Behavior, and Social Networking & 43 & $\mathrm{Q} 1$ & 1.31 & 119 & United States \\
International Journal of Environmental Research & 42 & $\mathrm{Q} 2$ & 0.82 & 78 & Switzerland \\
and Public Health & 27 & $\mathrm{Q} 1$ & 1.17 & 93 & United States \\
Journal of Interpersonal Violence & 23 & $\mathrm{Q} 1$ & 1.47 & 82 & United States \\
Aggressive Behavior & 22 & $\mathrm{Q} 1$ & 1 & 81 & Switzerland \\
Frontiers in Psychology & 22 & $\mathrm{Q} 1$ & 1.09 & 101 & United States \\
Journal of Adolescence & 20 & $\mathrm{Q} 1$ & 0.75 & 77 & United Kingdom \\
Children and Youth Services Review & 19 & $\mathrm{Q} 1$ & 1.09 & 32 & United States \\
Journal of School Violence & 18 & $\mathrm{Q} 1$ & 2.35 & 142 & Netherlands \\
Journal of Adolescent Health & 18 & $\mathrm{Q} 1$ & 1.52 & 101 & Netherlands \\
Journal of Youth and Adolescence & 15 & $\mathrm{Q} 2$ & 0.64 & 47 & Spain \\
Psicothema & 15 & $\mathrm{Q} 1$ & 1.38 & 117 & United Kingdom \\
BMC Public Health & 13 & $\mathrm{Q} 1$ & 0.57 & 76 & United States \\
Violence and Victims & 12 & $\mathrm{Q} 1$ & 1 & 46 & United States \\
Journal of Youth Studies & 12 & $\mathrm{Q} 2$ & 0.62 & 49 & United States \\
School Psychology International & 11 & $\mathrm{Q} 1$ & 0.85 & 26 & Spain \\
Comunicar & 10 & $\mathrm{Q} 1$ & 0.86 & 75 & United States \\
Journal of School Health & & & &
\end{tabular}

Journal productivity on adolescent cyberbullying was compared by applying Lotka's law, which showed that just 1 journal had 101 documents related to the subject, while 330 journals had only published 1 article during this period. The curve found was similar to an $R^{2}$ near 1, 0.718 (Figure 4 ).

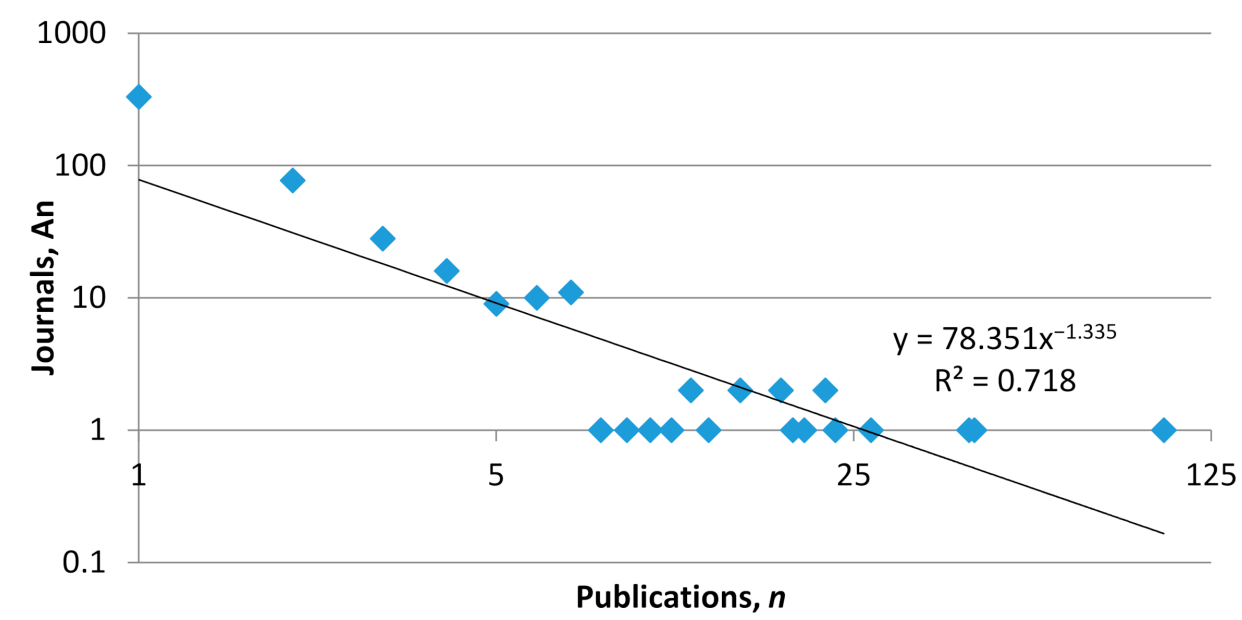

Figure 4. Plot of Lotka's law applied to journal productivity.

Figure 5 shows the co-authorship networks only of those authors who collaborated in at least four publications on adolescent cyberbullying, as the number of co-authorships was reduced for visualization with Pajek. The connection between authors is shown by the line that connects them, whether they are authors or co-authors of the same study. The transitivity coefficient of the co-authorship network was 0.82 . 


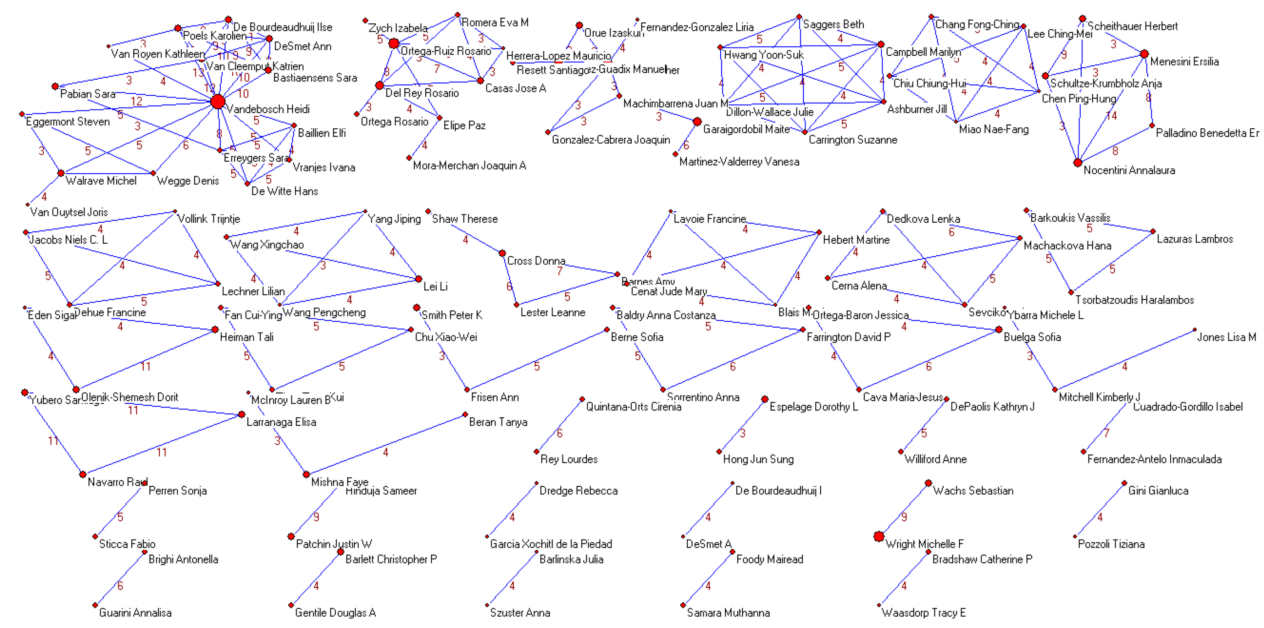

Figure 5. Co-authorship network. Map of collaboration by co-authors.

Figure 6 also shows the authors with the most publications on adolescent cyberbullying and their interaction. In this figure, the authors are the colored nodes or points, where the size of the node represents the number of articles published from 2010 through 2020. The author correlationships show how they group together for publishing. Clusters of the same color show the publication collaboration network, which includes a total of 121 authors distributed in 32 clusters, where the yellow cluster, made up of 10 authors led by Heidi Vandebosch, is the largest. This is followed by the red cluster comprising 15 authors, where Maite Garaigordobil and Esther Calvete are the authors with the most publications. In the green cluster, consisting of 12 authors, Rosario Ortega-Ruiz is outstanding with 28 articles. Ersilia Menesini, in the blue cluster of 12 authors, is also outstanding. The rest of the clusters are made up of fewer than 10 authors. The author with the most publications and the strongest link is Heidi Vandebosch, with a total of 37. Sameer Hinduja and Justin W. Patchin were cited the most with a total of 1158 citations.

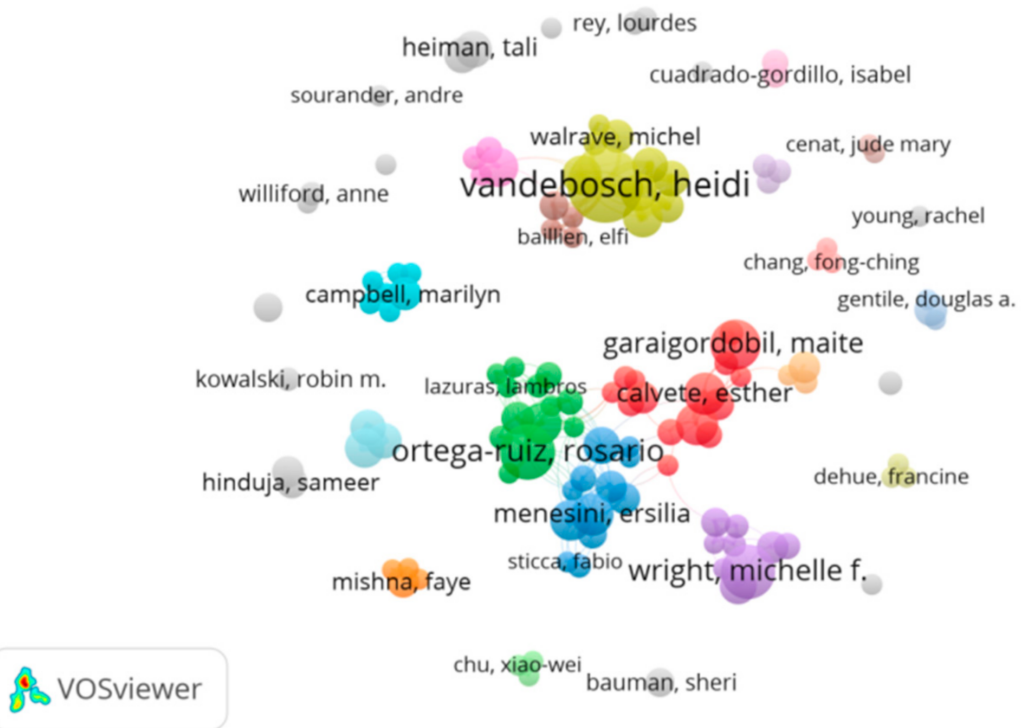

Figure 6. Authorship plot by number of publications.

Table 2 shows a selection of the main authors, where the total strength of the coauthorship bonds with other authors may be observed. Heidi Vandebosch is the strongest link, in addition to being the author with the most publications on the subject. She is followed by Rosario Ortega, who not only has 28 articles on cyberbullying to her name, but 
also was cited 803 times. Likewise, the repercussion of authors such as Sameer Hinduja and Justin W. Patchin, who, with only 9 publications, were cited 1158 times, is impressive. Peter K. Smith is also outstanding with 930 citations.

Table 2. Number of documents and citations and strength of co-authorship links.

\begin{tabular}{|c|c|c|c|}
\hline Author & Documents & Citations & Total Bond Strength \\
\hline Vandebosch, Heidi & 37 & 518 & 107 \\
\hline Ortega-Ruiz, Rosario & 28 & 803 & 57 \\
\hline Wright, Michelle F. & 22 & 197 & 15 \\
\hline Garaigordobil, Maite & 19 & 253 & 10 \\
\hline Menesini, Ersilia & 15 & 570 & 35 \\
\hline Calvete, Esther & 15 & 589 & 22 \\
\hline Gamez-Guadix, Manuel & 15 & 372 & 15 \\
\hline Nocentini, Annalaura & 14 & 513 & 35 \\
\hline Del Rey, Rosario & 14 & 331 & 31 \\
\hline Poels, Karolien & 13 & 300 & 53 \\
\hline Pabian, Sara & 13 & 210 & 29 \\
\hline Navarro, Raul & 13 & 199 & 22 \\
\hline Smith, Peter K. & 12 & 930 & 20 \\
\hline Van Cleemput, Katrien & 12 & 331 & 53 \\
\hline Heiman, Tali & 12 & 159 & 11 \\
\hline Wachs, Sebastian & 12 & 70 & 11 \\
\hline De Bourdeaudhuij, Ilse & 11 & 290 & 50 \\
\hline Desmet, Ann & 11 & 290 & 50 \\
\hline Olenik-Shemesh, Dorit & 11 & 159 & 11 \\
\hline Larranaga, Elisa & 11 & 142 & 22 \\
\hline Yubero, Santiago & 11 & 142 & 22 \\
\hline Bastiaensens, Sara & 10 & 276 & 50 \\
\hline Walrave, Michel & 10 & 253 & 13 \\
\hline Casas, Jose A. & 10 & 228 & 27 \\
\hline Barlett, Christopher P. & 10 & 100 & 5 \\
\hline Campbell, Marilyn & 10 & 88 & 17 \\
\hline Hinduja, Sameer & 9 & 1158 & 9 \\
\hline Patchin, Justin W. & 9 & 1158 & 9 \\
\hline Orue, Izaskun & 9 & 517 & 14 \\
\hline Scheithauer, Herbert & 9 & 344 & 23 \\
\hline Schultze-Krumbholz, Anja & 9 & 344 & 23 \\
\hline Buelga, Sofia & 9 & 197 & 10 \\
\hline Espelage, Dorothy I. & 9 & 174 & 6 \\
\hline Lei, Li & 9 & 56 & 12 \\
\hline Mishna, Faye & 9 & 54 & 8 \\
\hline
\end{tabular}

Figure 7 shows the year articles were published by color, where the predominant period is 2016-2017, followed by 2015-2016.

Figure 8 shows the concurrence of main words in the titles of the publications analyzed. The cluster colors show the coincidence of terms in the titles. That is, it clusters the words that appear together the most in document titles: cyberbully, cyber, cyber victimization, cyberbullying victimization, children, college student, risk factor, predictor. 


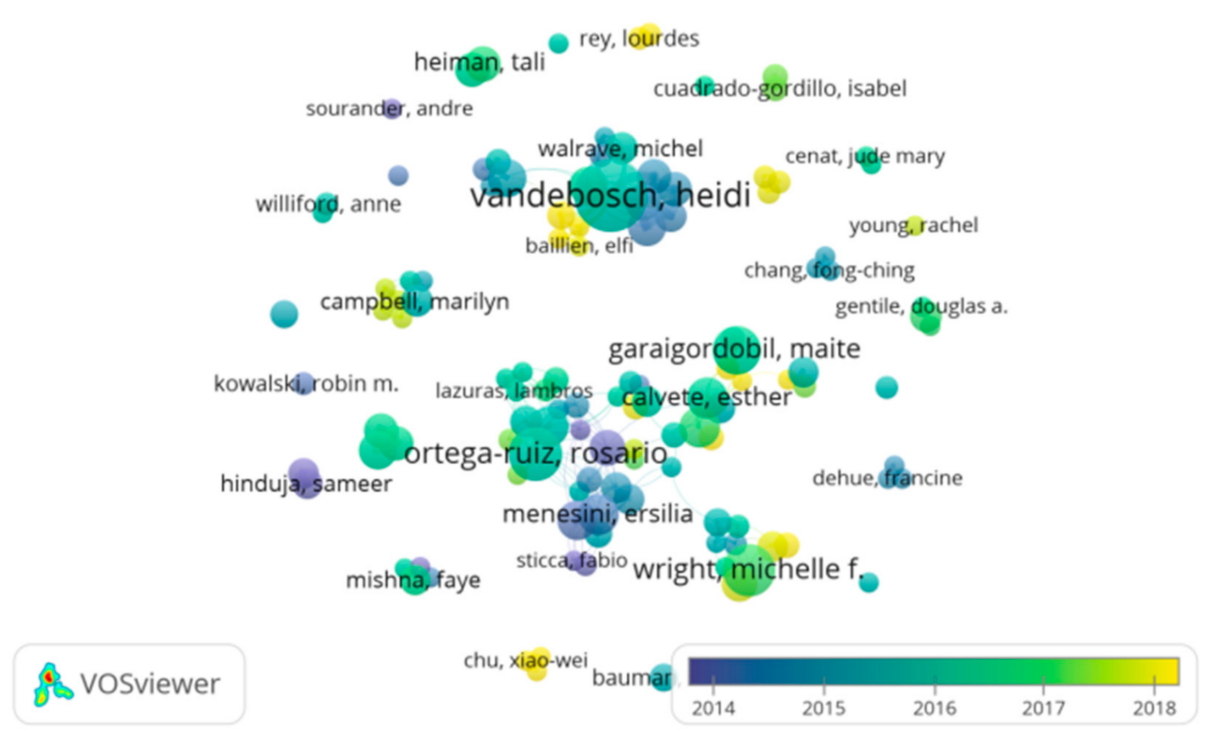

Figure 7. Visualization of authors by year.

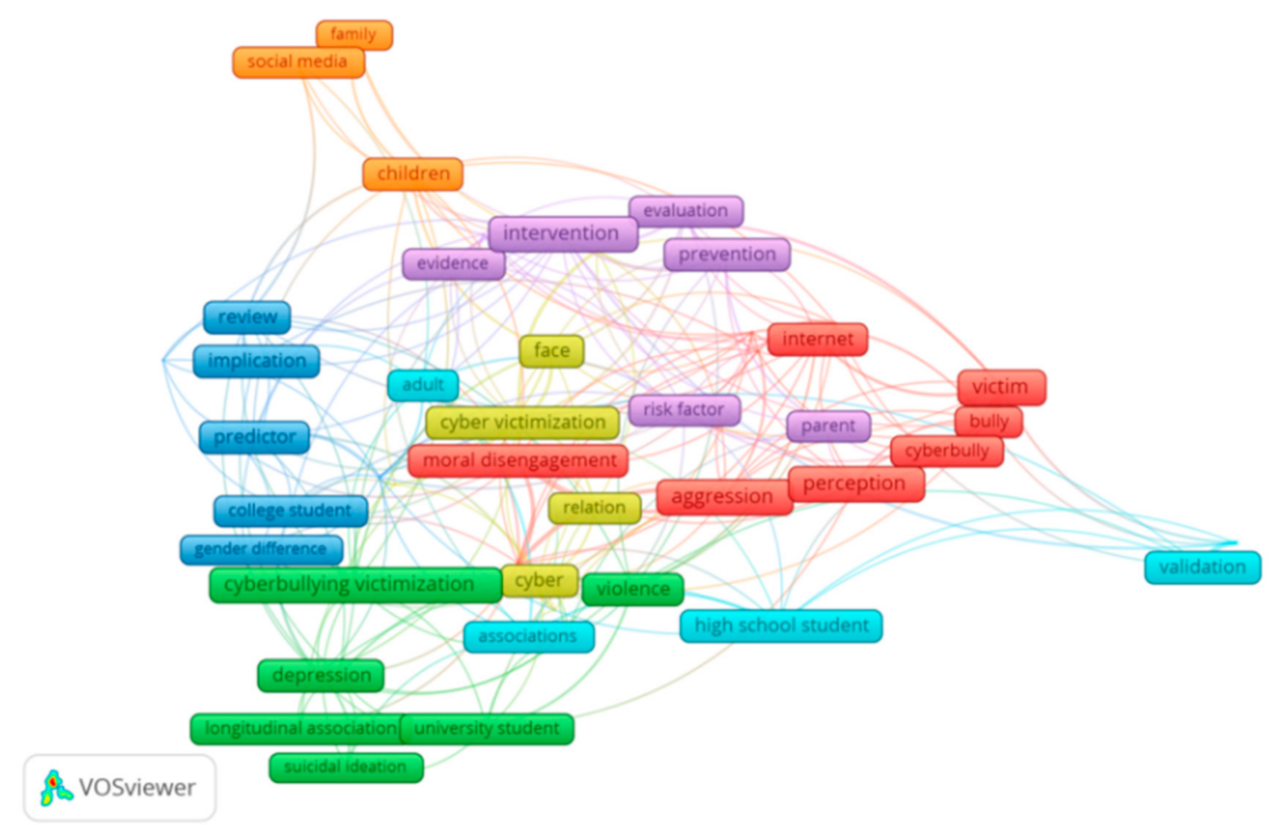

Figure 8. Coincidence of words in titles of publications on adolescent cyberbullying.

\section{Discussion}

The objective of this study was to find out the current panorama of international scientific bibliographic production related to adolescent cyberbullying in a bibliometric approach. This phenomenon has been recognized as a public health problem $[9,10]$. Its repercussions on society have led to an increase in the number of scientific publications, with a prevalence that varies from $6.5 \%$ to $35.4 \%$ in Europe and the United States [16]. In the last 10 years, there has been a continuous upward trend in the number of publications, and the most productive period was from 2017 to 2018 . Furthermore, scientific production increased rapidly from 2011, where the growth in number of publications coincided with the boom of social networking and cell phones and the appearance of a new type of multitasking consumer [39]. In spite of these data, investigative production on this phenomenon is much lower than on bullying [36], as some authors do not consider it a different phenomenon, but a type of bullying [14]. 
The predominant language was English, as already described in other studies, as it is the main language of publication and communication in research [40], followed by Spanish. In line with other reviews and analyses of this phenomenon, the United States was the country with the highest scientific production, followed by Spain, both standing out from the rest as the main drivers of publications on adolescent cyberbullying $[33,37]$. The category with the highest production related to the subject was social sciences, being the area that studies social behavior.

Several main journals were identified, as in any field of research, not only due to the frequency of publications, but also due to the mentions they received, which are equally important. Computers in Human Behavior, which is an academic journal on the use of computers in psychology and the psychological impact of their use in society, is the journal with the largest number of publications on the subject of study, standing out from the rest by a wide difference, because of its production statistics, given the large number of volumes it publishes yearly.

The analysis of authors demonstrated that many researchers are approaching the subject of adolescent cyberbullying. Thirty-two groups were identified, and in most groups, the collaboration network extends to researchers in other countries. These groups are made up of researchers from areas where the cyberbullying prevalence rates are highest, such as Europe and the United States [16], and therefore, their interest in the subject as the focus of research is higher.

This study has some limitations, one of which is the restriction of the search to a single database, Web of Science, and the choice of the descriptors used for the search. Although it was attempted to integrate all the terms related to adolescence, some studies may have been excluded because they were otherwise described. Therefore, future studies should widen both search terms and databases. In addition, as a potential line of future research, we recommend the need to carry out a systematic review and/or meta-analysis, analyzing the contents of the studies carried out, and the variables related to this problem. A reference point for research in this field, and as a basis for future reviews of its development and progress over time, could thus be found.

\section{Conclusions}

In spite of the limitations, these results have a significant implication for understanding how new technologies and social networking tools, when poorly managed and combined with psychological and social maladjustments, can lead to negative repercussions on the lives of individuals. This bibliometric analysis also enabled us to communicate the key findings to the researchers, who can start up the prevention and intervention mechanisms necessary.

Moreover, the reason that the production related to adolescent cyberbullying is not decreasing, but on the contrary is growing, is that institutions and researchers are finding that it has become a severe and growing public health problem.

Therefore, the results of this study have practical implications in education and health, especially in identifying areas for future research that should be considered for the study and design of interventions. In addition, information on the areas where most studies are concentrated will enable the identification of less studied areas, where it is possible to continue exploring other resources for education.

Author Contributions: A.B.B.M., M.d.M.M.J., and M.d.C.P.-F. contributed to the conception and design of the review. M.d.M.S.M., Á.M.M., and M.S. applied the search strategy. All authors applied the selection criteria. All authors completed the assessment of risk of bias. All authors analyzed and interpreted the data. M.d.M.M.J., M.d.C.P.-F., A.B.B.M., M.d.M.S.M., Á.M.M., and M.S. wrote the manuscript. Á.M.M. and J.J.G.L. edited the manuscript. M.d.C.P.-F. is responsible for the overall project. All authors have read and agreed to the published version of the manuscript.

Funding: This research received no external funding. 
Institutional Review Board Statement: The study was approved by the University of Almería Bioethics Committee (Ref: UALBIO2018/015).

Informed Consent Statement: Not applicable.

Data Availability Statement: The data that support the findings of this study are available from the corresponding author upon reasonable request.

Acknowledgments: The present study was undertaken in collaboration with the Peer Violence and Alcohol and Tobacco Use in Secondary Education Program, an augmented reality program for detection and intervention (Reference: EDU2017-88139-R), funded by the State Research Program, Development and Innovation Oriented to the Challenges of Society, within the framework of the State Plan for Scientific and Technical Research and Innovation, with cofinancing from Structural Funds of the European Union. Part of this work was developed thanks to the financing of University Teaching Training in Deficit Areas, Gerty Cori Aid, for the hiring of research staff in predoctoral training, granted by María del Mar Simón Márquez.

Conflicts of Interest: The authors declare no conflict of interest.

\section{References}

1. Mateo, C.M.; Hernández, M.P.; Cabrero, R.S. El bienestar psicológico en la adolescencia: Variables psicológicas asociadas y predictoras. Eur. J. Educ. Psychol. 2019, 12, 139. [CrossRef]

2. Linares, J.J.G.; Pérez-Fuentes, M.D.C.; Martínez, J.J.C.; de la Rosa, A.L.; Jurado, M.D.M.M. Interpersonal Value Profiles and Analysis to Adolescent Behavior and Social Attitudes: Perfiles de valores interpersonales y análisis de conductas y actitudes sociales de adolescentes. Rev. Psicodidáctica 2015, 20, 321-337. [CrossRef]

3. Pérez-Fuentes, M.C.; Álvarez-Bermejo, J.A.; Molero, M.M.; Gázquez, J.J.; López, M.A. Scholar violence and academic achievement (VERA): Augmented Reality Application. Eur. J. Investig. Health Psychol. Educ. 2011, 1, 71-84. [CrossRef]

4. Romero-Abrio, A.; Martínez-Ferrer, B.; Sánchez-Sosa, J.C.; Musitu, G. A psychosocial analysis of relational aggression in Mexican adolescents based on sex and age. Psicothema 2019, 31, 88-93.

5. Álvarez-García, D.; García, T.; Núñez, J.C. Predictors of school bullying perpetration in adolescence: A systematic review. Aggress. Violent Behav. 2015, 23, 126-136. [CrossRef]

6. Linares, J.J.G.; Díaz, A.J.C.; Fuentes, M.D.C.P.; Acién, F.L.; Cangas, A.J. Teachers' perception of school violence in a sample from three european countries. Eur. J. Psychol. Educ. 2009, 24, 49-59. [CrossRef]

7. Abuín-Vences, N.; Maestro-Espínola, L.; Cordón-Benito, D. Internet, smartphones y redes sociales como factores determinan-tes en el incremento de casos de ciberacoso = Internet, smartphones and social networks as determining factors in the increase in cyberbullying cases. Rev. Espac. 2019, 40, 23.

8. Dominguez-Alonso, J.; Vazquez-Varela, E.; Nuñez-Lois, S. Cyberbullying escolar: Incidencia del teléfono móvil e internet en adolescentes. RELIEVE Rev. Electrónica Investig. Eval. Educ. 2017, 23, 1-11. [CrossRef]

9. Craig, W.; Harel-Fisch, Y.; Fogel-Grinvald, H.; Dostaler, S.; Hetland, J.; Simons-Morton, B.; Molcho, M.; de Mato, M.G.; Overpeck, M.; Due, P.; et al. A cross-national profile of bullying and victimization among adolescents in 40 countries. Int. J. Public Health 2009, 54, 216-224. [CrossRef]

10. World Health Organization. Global Status Report on Violence Prevention 2014. Available online: http:/ /www.who.int/violence_ injury_prevention/violence/status_report/2014/report/report/en/ (accessed on 26 January 2021).

11. Fahy, A.E.; Stansfeld, S.A.; Smuk, M.; Smith, N.R.; Cummins, S.; Clark, C. Longitudinal Associations Between Cyberbullying Involvement and Adolescent Mental Health. J. Adolesc. Healeh 2016, 59, 502-509. [CrossRef] [PubMed]

12. Olweus, D. Cyberbullying: An overrated phenomenon? Eur. J. Dev. Psychol. 2012, 9, 520-538. [CrossRef]

13. Kowalski, R.M.; Giumetti, G.W.; Schroeder, A.N.; Lattanner, M.R. Bullying in the digital age: A critical review and meta-analysis of cyberbullying research among youth. Psychol. Bull. 2014, 140, 1073-1137. [CrossRef] [PubMed]

14. Beltrán-Catalán, M.; Zych, I.; Ortega-Ruiz, R.; Lorent, V.J. Victimisation through bullying and cyberbullying: Emotional intelligence, severity of victimisation and technology use in different types of victims. Psicothema 2018, 30, 183-188. [PubMed]

15. Gordillo, I.C.; Antelo, I.F.; Parra, G.M.-M.; Fernández-Antelo, I. Pueden las víctimas de bullying convertirse en agresores del ciberespacio? Estudio en población adolescente. Eur. J. Investig. Health Psychol. Educ. 2019, 9, 71-81. [CrossRef]

16. Bottino, S.M.B.; Bottino, C.M.C.; Regina, C.G.; Correia, A.V.L.; Ribeiro, W.S. Cyberbullying and adolescent mental health: Systematic review. Cad. Saúde Pública 2015, 31, 463-475. [CrossRef]

17. Aboujaoude, E.; Savage, M.W.; Starcevic, V.; Salame, W.O. Cyberbullying: Review of an Old Problem Gone Viral. J. Adolesc. Health 2015, 57, 10-18. [CrossRef] [PubMed]

18. Lara-Beltrán, M.D. Afrontamiento, afecto y tabaco en una muestra de adolescentes españoles. Rev. Psicol. Clín. Niños Adolesc. 2019, 6, 9-14. [CrossRef]

19. Handono, S.G.; Laeheem, K.; Sittichai, R. Factors related with cyberbullying among the youth of Jakarta, Indonesia. Child. Youth Serv. Rev. 2019, 99, 235-239. [CrossRef] 
20. Rodríguez-Hidalgo, A.J.; Solera, E.; Calmaestra, J. Psychological Predictors of Cyberbullying According to Ethnic-Cultural Origin in Adolescents: A National Study in Spain. J. Cross-Cult. Psychol. 2018, 49, 1506-1522. [CrossRef]

21. Cañas, E.; Estévez, E.; Marzo, J.C.; Piqueras, J.A. Psychological adjustment in cybervictims and cyberbullies in secondary education. An. Psicol. 2019, 35, 434-443. [CrossRef]

22. Martínez, I.; Murgui, S.; Garcia, O.F.; Garcia, F. Parenting in the digital era: Protective and risk parenting styles for traditional bullying and cyberbullying victimization. Comput. Hum. Behav. 2019, 90, 84-92. [CrossRef]

23. Chu, X.-W.; Fan, C.-Y.; Liu, Q.-Q.; Zhou, Z.-K. Cyberbullying victimization and symptoms of depression and anxiety among Chinese adolescents: Examining hopelessness as a mediator and self-compassion as a moderator. Comput. Hum. Behav. 2018, 86, 377-386. [CrossRef]

24. Livazović, G.; Ham, E. Cyberbullying and emotional distress in adolescents: The importance of family, peers and school. Heliyon 2019, 5, e01992. [CrossRef]

25. Pengpid, S.; Peltzer, K. Bullying victimization and externalizing and internalizing symptoms among in-school adolescents from five ASEAN countries. Child. Youth Serv. Rev. 2019, 106, 104473. [CrossRef]

26. Álvarez-García, D.; Núñez, J.C.; García, T.; Barreiro-Collazo, A.; Barreiro-Collazo, A.A. Individual, Family, and Community Predictors of Cyber-aggression among Adolescents. Eur. J. Psychol. Appl. Leg. Context 2018, 10, 79-88. [CrossRef]

27. Llorca-Mestre, A.; Malonda-Vidal, E.; Samper-García, P. Prosocial reasoning and emotions in young offenders and non-offenders. Eur. J. Psychol. Appl. Leg. Context 2017, 9, 65-73. [CrossRef]

28. Garcia-Hermoso, A.; Oriol-Granado, X.; Correa-Bautista, J.E.; Ramírez-Vélez, R. Association between bullying victimization and physical fitness among children and adolescents. Int. J. Clin. Health Psychol. 2019, 19, 134-140. [CrossRef]

29. Perez-Gramaje, A.F.; Garcia, O.F.; Reyes, M.; Serra, E.; Garcia, F. Parenting Styles and Aggressive Adolescents: Relationships with Self-esteem and Personal Maladjustment. Eur. J. Psychol. Appl. Leg. Context 2019, 12, 1-10. [CrossRef]

30. Moffitt, T.E. Male antisocial behaviour in adolescence and beyond. Nat. Hum. Behav. 2018, 2, 177-186. [CrossRef] [PubMed]

31. Lee, Y.C.; Wu, W.-L. Factors in cyber bullying: The attitude-social influence-efficacy model. An. Psicol. 2018, 34, 324-331. [CrossRef]

32. Lee, C.; Shin, N. Prevalence of cyberbullying and predictors of cyberbullying perpetration among Korean adolescents. Comput. Hum. Behav. 2017, 68, 352-358. [CrossRef]

33. Zych, I.; Ortega-Ruiz, R.; del Rey, R. Systematic review of theoretical studies on bullying and cyberbullying: Facts, knowledge, prevention, and intervention. Aggress. Violent Behav. 2015, 23, 1-21. [CrossRef]

34. De Bellis, N. Bibliometrics and Citation Analysis: From the Science Citation Index to Cybermetrics; Scarecrow Press Inc.: Lanham, MD, USA, 2009.

35. Pan, X.; Yan, E.; Cui, M.; Hua, W. Examining the usage, citation, and diffusion patterns of bibliometric mapping software: A comparative study of three tools. J. Inf. 2018, 12, 481-493. [CrossRef]

36. Herrera-López, M.; Romera, E.M.; Ortega-Ruiz, R. Bullying y Cyberbullying en Latinoamérica. Un estudio bibliométrico. = Bullying and Cyberbullying in Latin America. A bibliometric study. Rev. Mex. Investig. Educ. 2018, 23, $125-155$.

37. Cañón, R.; Grande, M.; Ferrero, E. Ciberacoso: Revisión de la literatura educativa en español. (Cyberbullying: A review of the educational literatura). RELATEC 2018, 17, 87-99. [CrossRef]

38. Garaigordobil, M.; Martínez-Valderrey, V. Effects of Cyberprogram 2.0 on“face-to-face" bullying, cyberbullying, and empathy. Psicothema 2015, 27, 45-51.

39. Morales, E. El smartphone como motor de una nueva incertidumbre social: La importancia de las redes sociales en la comunicación móvil de los jóvenes españoles en la sociedad de la inmediatez. = The smartphone as the engine of a new social uncer-tainty: The importance of social networks in the mobile communication of young Spanish people in the society of immediacy. Prism. Soc. 2012, 8, 87-115.

40. Curry, M.J.; Lillis, T. Multilingual Scholars and the Imperative to Publish in English: Negotiating Interests, Demands, and Rewards. TESOL Q. 2004, 38, 663. [CrossRef]

41. Anderson, E.L.; Steen, E.; Stavropoulos, V. Internet use and Problematic Internet Use: A systematic review of longitudinal research trends in adolescence and emergent adulthood. Int. J. Adolesc. Youth 2017, 22, 430-454. [CrossRef]

42. Persson, O.R.; Danell, R.; Wiborg-Schneider, J. How to use Bibexcel for various types of bibliometric analysis. In Celebrating Scholarly Communication studies: A Festschrift for Olle Persson at his 60th Birthday; Åström, F., Danell, R., Larsen, B., Schneider, J., Eds.; International Society for Scientometrics and Informetrics: Leuven, Belgium, 2009; pp. 9-24.

43. Batagelj, V.; Mrvar, A. Pajek-A program for large network analysis. Connections 1998, 21, 47-57.

44. Van Eck, N.J.; Waltman, L. VOSviewer Manual [en Línea]. Available online: https://www.vosviewer.com/documentation/ Manual_VOSviewer_1.5.5.pdf (accessed on 5 December 2013). 